\title{
Socio-Demographic Determinants of Exclusive Breastfeeding Practices Among Nursing Mothers in Enugu State
}

\author{
Anthonia C. Ogbe ${ }^{1}$, Clementina U. Nwankwo ${ }^{2}$, Theresa O. Agbele ${ }^{3} \&$ Joshua C. Nwambo ${ }^{4}$ \\ ${ }^{1}$ Enugu State Ministry of Health, Public Health Department, Enugu, Nigeria \\ ${ }^{2}$ Department of Nursing Science, Nnamdi Azikiwe University, Awka, Nigeria \\ ${ }^{3}$ Federal Medical Center, Asaba, Nigeria \\ ${ }^{4}$ American University of Nigeria Health Center, Yola, Nigeria \\ Correspondence: Joshua C. Nwambo, AUN Health Center, American University of Nigeria, Yola, Nigeria.
}

Received: April 14, 2020

doi:10.20849/ijsn.v5i2.736
Accepted: May 2, 2020

Online Published: May 20, 2020

URL: https://doi.org/10.20849/ijsn.v5i2.736

\begin{abstract}
Exclusive breastfeeding (EBF) plays a pivotal role in determining the optimal health and development of infants with reduction in infant mortality. This study focuses on those factors which place nursing mothers in the likelihood of not adopting and practicing EBF. It is a descriptive study that utilized a multi-stage sampling technique. A structured questionnaire, mean and standard deviation were used. The result shows that the EBF practice among nursing mothers is high with a grand mean and standard deviation of $2.75(0.61)$. Those with secondary qualification and below had 3.10(0.37) while tertiary had $2.23(0.41)$. Mothers aged 25 and below had $3.39(0.14)$ and above age 25 had 2.57(0.52).Parity of 1-4 had $2.93(0.47)$ while parity of 5 and above had 1.93 (0.34). Married and single mothers had $2.75(0.61)$ and $1.26(0.05)$ respectively. Effective EBF education is needed to reduce socio-demographic factors that hinder mothers' practice of EBF.
\end{abstract}

Keywords: exclusive breastfeeding, infant mortality, adoption, practice, nursing mothers

\section{Introduction}

Breast milk is the safest and most natural food for infants. When the baby is fed on breast milk only, it is called Exclusive Breast-Feeding (EBF) (World Health Organization, WHO, 2004). According to WHO (2003), "EBF is the provision of no other food or drink, not even water, except breast milk for at least six months of life apart from drops or syrups consisting of vitamins, mineral supplements or medicine, and nothing else"(Setegn, Belachew, Gerbaba et al., 2012). Exclusive breastfeeding when practiced for the first 6 months has shown to improve the survival chances of newborn (WHO, 2003). It is cost effective, natural, and a proven means for infection prevention in infants (WHO, 2004). Its role is crucial and influences the health, growth, and development of infants, and is associated with a reduced incidence of early life diseases and condition (Chung \& Magula, 2007).

Prior to 2001, the recommended period for EBF by the WHO was 4-6 months after which any fluid or food other than breast milk may be introduced. However, following series of new findings, reviews, and consultation, the recommendation for EBF was encouraged to be for the first 6 months of life. This recommendation was further supported in a systematic review approved by the WHO which compared the benefits of EBF for 3-4 months and 6 months period. Findings from the review clearly demonstrated that infants in the second category (EBF for 6months) were less susceptible and had fewer cases of gastrointestinal infection and normal growth compared to the infants who had EBF for 3-4 months (Fewtrell, Morgan, Duggan et al., 2007). Ladomenou, Moschandreas, Kafatos et al in 2010 reiterated that nursing mothers that breastfed their babies exclusively as recommended by WHO had fewer cases of infection than those infants that were either partially or not breastfed. American Academy of Pediatrics (AAP, 2000) emphasized that breast-feeding provides an infant complete nutritional needs, protection from infectious diseases, increases their physical and mental growth and development and equally benefit maternal health by reducing the risk of haemorrhage, osteoporosis, ovarian, uterine and breast cancers. It is recommended that EBF lasts for the first six months of life and then followed by supplemented breast-feeding for at least one year (AAP, 2000), while WHO recommends that supplemented breast-feeding be continued up to two years or more (WHO, 2003). 
Globally only 38 percent of infants are exclusively breast fed during the first four months of life and complimentary feeding practices are often ill timed, inappropriate, and unsafe (WHO, 2004). In developed countries where the baby friendly- Hospital - initiative has begun in earnest, EBF rates are increasing such as Canada, China, and USA (WHO, 2003).

Despite the huge benefits of EBF and ill-effects of not exclusively breastfeeding, EBF is not extensively adopted and practiced in the developing countries (Cai, Wardlaw \& Brown, 2012). In Nigeria, EBF adoption and practice is still below the recommended WHO and UNICEF standard of 90 percent in children below the age of 6 months (WHO \& UNICEF, 2009). Oliko (2009) conducted a study in Lagos State and found out that non acceptance and practice of EBF was associated with socio-demographic factors. Similarly, the present study focuses on those factors which may directly or indirectly place nursing mothers in the study area (Enugu State) in the likelihood of not adopting and practicing exclusive breast-feeding.

\subsection{Research Questions}

The following research questions guided the study.

i. What are the breast-feeding practices of nursing mothers in Enugu State that adopt exclusive breast-feeding?

ii. What are the breast-feeding practices of nursing mothers in Enugu State that adopt exclusive breast-feeding in relation to their level of education?

iii. What are the breast-feeding practices of nursing mothers in Enugu State that adopt exclusive breast-feeding in relation to their age?

iv. What are the breast-feeding practices of nursing mothers in Enugu State that adopt exclusive breast-feeding in relation to their parity?

v. What are the breast-feeding practices of nursing mothers in Enugu State that adopt exclusive breast-feeding in relation to their marital status?

\section{Methods}

\subsection{Research Design}

The research design adopted was a descriptive survey design.

\subsection{Area of the Study}

The area of the study is Enugu State. It is one of the states in the South East geopolitical Zone of Nigeria. Enugu State has a population figure of 3,267,837 persons (National Population Commission, NPC, 2006). Enugu is noted as a civil service state with those at the rural areas practicing peasant farming while there are equally many traders and artisans. It is not a highly industrialized state but has the presence of both federal and state schools and health institutions.

\subsection{Population of the Study}

The population that was used for the study involves nursing mothers in the seventeen local government areas of Enugu State who visit the available Health centres in this research.

\subsection{Sample and Sampling Techniques}

Multi-stage sampling technique was used. By this the 17 LGAs in Enugu State were divided into urban and rural LGAs. There are 4 urban LGAs while the rest (13) are rural. In the first stage, 2 urban and 3 rural LGAs was randomly selected using balloting without replacement. In the second stage, two health facilities were randomly selected without replacement from each of the selected LGAs. In the third stage, 412 nursing mothers who indicated to be adopting EBF were used as the actual sample size of the study.

\subsection{Instrument for Data Collection}

The instrument for data collection was a 27-item structured questionnaire known as Exclusive Breastfeeding Practicing Questionnaire (EBFPQ) developed by the researchers. The questionnaire was made up of Sections A and B. Section A contains 4 items designed to elicit responses on the socio demographic factors of the respondents on level of education, age, parity and marital status of nursing mothers. Section B contains 23 items to elicit responses on the indices of exclusive breast-feeding adoption and practice. The respondents were required to indicate on a four-rank rating scale on how they practice exclusive breast-feeding. The response columns of EBFPQ were allocated scores as follows: very often (4), often (3), sometimes (2), and never (1). 


\subsection{Validation and Reliability of the Instrument}

The face and content validity of the instrument were obtained. The internal consistency of the instrument (EBFPQ) using Cronbach Apha reliability coefficient was ascertained and a reliability coefficient of 0.76 was obtained.

\subsection{Method of Data Collection}

The questionnaire was administered by the researchers and four trained research assistants.

\subsection{Method of Data Analysis}

The data generated from the study were analyzed using mean and standard deviation for the research questions. A decision rule based on mean rating of 2.5 was set. The items with mean rating below 2.5 were considered as low practice while items with mean at 2.5 and above were regarded as high practice.

\section{Results}

Research Question One: What are the breastfeeding practices of nursing mothers in Enugu State that adopt exclusive breast-feeding?

Table 1. Mean ratings of the respondents on the breastfeeding practice of nursing mothers that adopt exclusive breast feeding $(\mathrm{n}=405)$

\begin{tabular}{|c|c|c|c|c|}
\hline $\mathbf{S} / \mathbf{N}$ & Items & Meān & SD & Decision \\
\hline 5 & Initiation of breast-feeding within a half hour of birth & 1.57 & 0.81 & $\begin{array}{ll}\text { Low } & \text { level } \\
\text { (LL) }\end{array}$ \\
\hline 6 & $\begin{array}{l}\text { Making sure the baby gets the first yellow milk which is the first } \\
\text { immunization to the baby. }\end{array}$ & 3.61 & 0.55 & $\begin{array}{l}\text { High level } \\
\text { (HL) }\end{array}$ \\
\hline 7 & Feeding the baby on demand & 2.90 & 0.78 & HL \\
\hline 8 & Expression of breast milk when away from home & 1.13 & 0.47 & LL \\
\hline 9 & Breast feed in the public without shame & 2.32 & 0.82 & LL \\
\hline 10 & Continuing breastfeeding for six months even when pregnant & 1.04 & 0.18 & $\overline{\mathrm{LL}}$ \\
\hline 11 & Breastfeed up to 8 -10 times in 24 hours & 3.45 & 0.63 & HL \\
\hline 12 & $\begin{array}{l}\text { After introduction of complimentary feeds at six months continued } \\
\text { breastfeeding up to one year. }\end{array}$ & 3.14 & 1.02 & HL \\
\hline 13 & $\begin{array}{l}\text { After introduction of complimentary feeds at six months continued } \\
\text { breastfeeding up to two years }\end{array}$ & NIL & NIL & NIL \\
\hline 14 & Breastfeed until the baby is satisfied & 2.95 & 0.60 & HL \\
\hline 15 & No giving of artificial teat or pacifiers to breastfeeding infants & 3.14 & 0.81 & HL \\
\hline 16 & $\begin{array}{l}\text { Feeding the baby without food other than breast milk for the first six } \\
\text { months }\end{array}$ & 3.74 & 0.45 & HL \\
\hline 17 & Breastfeeding the baby without giving water for the first six months & 3.49 & 0.55 & $\mathrm{HL}$ \\
\hline 18 & $\begin{array}{l}\text { Ensures that baby's mouth is well attached to the areola for the baby to } \\
\text { get enough milk }\end{array}$ & 3.25 & 0.70 & $\mathrm{HL}$ \\
\hline 19 & $\begin{array}{l}\text { Making sure that baby is not sucking the nipple of the breast to avoid } \\
\text { sore nipple }\end{array}$ & 3.82 & 0.61 & HL \\
\hline 20 & Proper massaging of baby's back to ensure adequate belching & 3.26 & 0.65 & $\mathrm{HL}$ \\
\hline 21 & Ensure good personal hygiene to protect the baby from having diarrhea & 3.67 & 0.48 & HL \\
\hline 22 & $\begin{array}{l}\text { Continuing breast milk as it does not sour if a mother does not } \\
\text { breastfeed her baby for some days }\end{array}$ & 1.05 & 0.21 & LL \\
\hline 23 & Breastfeeding the baby adequately at night & 3.50 & 0.59 & HL \\
\hline 24 & $\begin{array}{l}\text { Practising rooming-in which allows mother and infant to remain } \\
\text { together } 24 \text { hours for the first day of life }\end{array}$ & 2.91 & 0.92 & HL \\
\hline 25 & Having sex during breastfeeding as it does no harm to the baby & 2.49 & 0.93 & LL \\
\hline 26 & Increase fluid to promote adequate breast flow & 3.25 & 0.75 & HL \\
\hline \multirow[t]{3}{*}{27} & Sleeping on the same bed with your baby & 3.45 & 0.63 & HL \\
\hline & Cluster Total & 63.13 & & \\
\hline & Cluster Mean & 2.75 & 0.61 & HL \\
\hline
\end{tabular}


Table 1 shows that high mean scores for items $6,7,11,12,14,15,16,17,18,19,20,21,23,24,26$ and 27 respectively. On the contrary, low mean scores (below 2.50) were obtained for items 5, 8, 9, 10,22 and 25 respectively. No scores for item 13. A grand mean of 2.75, with standard deviation of 0.61 , was obtained for all the 23 items. This indicates that the nursing mothers in Enugu State generally practice exclusive breastfeeding.

Research Question Two: What are the breast-feeding practices of nursing mothers in Enugu State that adopt exclusive breast-feeding in relation to their level of education?

Table 2. Mean ratings of nursing mothers in Enugu State regarding their exclusive breast-feeding practices according to level of education

\begin{tabular}{|c|c|c|c|c|c|c|c|}
\hline \multirow[t]{2}{*}{$\mathbf{S} / \mathbf{N}$} & \multirow[t]{2}{*}{ Items } & \multicolumn{3}{|c|}{ Sec. edu\& below $=239$} & \multicolumn{3}{|c|}{ Tertiary edu $=166$} \\
\hline & & Mean & SD & Decision & Mean & SD & Decision \\
\hline 5 & $\begin{array}{l}\text { Initiation of breast-feeding within a } \\
\text { half hour of birth }\end{array}$ & 1.97 & 0.86 & $\begin{array}{l}\text { Low Level } \\
\text { (LL) }\end{array}$ & 1.00 & 0.00 & $\begin{array}{ll}\text { Low } & \text { Level } \\
\text { (LL) } & \end{array}$ \\
\hline 6 & $\begin{array}{l}\text { Making sure the baby gets the first } \\
\text { yellow milk which is the first } \\
\text { immunization to the baby. }\end{array}$ & 4.00 & 0.00 & $\begin{array}{l}\text { High Level } \\
\text { (HL) }\end{array}$ & 3.05 & 0.48 & $\begin{array}{l}\text { High Level } \\
(\mathrm{HL})\end{array}$ \\
\hline 7 & Feeding the baby on demand & 3.40 & 0.49 & HL & 2.17 & 0.50 & $\mathrm{LL}$ \\
\hline 8 & $\begin{array}{l}\text { Expression of breast milk when away } \\
\text { from home }\end{array}$ & 1.21 & 0.61 & LL & 1.00 & 0.00 & $\mathrm{LL}$ \\
\hline 9 & $\begin{array}{l}\text { Breast feed in the public without } \\
\text { shame }\end{array}$ & 2.79 & 0.67 & HL & 1.64 & 0.48 & LL \\
\hline 10 & $\begin{array}{l}\text { Continuing breastfeeding for six } \\
\text { months even when pregnant }\end{array}$ & 1.06 & 0.24 & LL & 1.00 & 0.00 & LL \\
\hline 11 & Breastfeed up to 8 -10 times in 24 hours & 3.89 & 0.32 & HL & 2.83 & 0.41 & $\mathrm{HL}$ \\
\hline 12 & $\begin{array}{l}\text { After introduction of complimentary } \\
\text { feeds at six months continued } \\
\text { breastfeeding up to one year. }\end{array}$ & 3.83 & 0.37 & HL & 2.13 & 0.80 & LL \\
\hline 13 & $\begin{array}{l}\text { After introduction of complimentary } \\
\text { feeds at six months continued } \\
\text { breastfeeding up to two years }\end{array}$ & . & . & · & . & $\cdot$ & $\cdot$ \\
\hline 14 & Breastfeed until the baby is satisfied & 3.26 & 0.44 & $\mathrm{HL}$ & 2.50 & 0.54 & $\mathrm{HL}$ \\
\hline 15 & $\begin{array}{l}\text { No giving of artificial teat or pacifiers } \\
\text { to breastfeeding infants }\end{array}$ & 3.63 & 0.48 & HL & 2.43 & 0.66 & LL \\
\hline 16 & $\begin{array}{l}\text { Feeding the baby without food other } \\
\text { than breast milk for the first six months }\end{array}$ & 4.00 & 0.00 & $\mathrm{HL}$ & 3.37 & 0.52 & $\mathrm{HL}$ \\
\hline 17 & $\begin{array}{l}\text { Breastfeeding the baby without giving } \\
\text { water for the first six months }\end{array}$ & 3.87 & 0.33 & HL & 2.93 & 0.26 & $\mathrm{HL}$ \\
\hline 18 & $\begin{array}{l}\text { Ensures that baby's mouth is well } \\
\text { attached to the areola for the baby to } \\
\text { get enough milk }\end{array}$ & 3.65 & 0.48 & $\mathrm{HL}$ & 2.66 & 0.56 & $\mathrm{HL}$ \\
\hline 19 & $\begin{array}{l}\text { Making sure that baby is not sucking } \\
\text { the nipple of the breast to avoid sore } \\
\text { nipple }\end{array}$ & 4.00 & 0.00 & HL & 3.57 & 0.91 & $\mathrm{HL}$ \\
\hline 20 & $\begin{array}{l}\text { Proper massaging of baby's back to } \\
\text { ensure adequate belching }\end{array}$ & 3.65 & 0.48 & $\mathrm{HL}$ & 2.71 & 0.46 & $\mathrm{HL}$ \\
\hline 21 & $\begin{array}{l}\text { Ensure good personal hygiene to } \\
\text { protect the baby from having diarrhea }\end{array}$ & 4.00 & 0.00 & HL & 3.20 & 0.44 & HL \\
\hline
\end{tabular}




\begin{tabular}{lllllllll}
\hline 22 & $\begin{array}{l}\text { Continuing breast milk as it does not } \\
\text { sour if a mother does not breastfeed } \\
\text { her baby for some days }\end{array}$ & & 0.27 & LL & 1.00 & 0.00 & LL \\
\hline 23 & $\begin{array}{l}\text { Breastfeeding the baby adequately at } \\
\text { night }\end{array}$ & 3.90 & 0.30 & HL & 2.92 & 0.40 & HL \\
\hline 24 & $\begin{array}{l}\text { Practising rooming in which allow } \\
\text { mother and infant to remain together } \\
\text { 24 hours for the first day of life }\end{array}$ & & 0.50 & HL & 2.11 & 0.80 & LL \\
\hline 25 & $\begin{array}{l}\text { Having sex during breastfeeding as it } \\
\text { does no harm to the baby }\end{array}$ & 3.00 & 0.87 & HL & 1.77 & 0.42 & LL \\
\hline 26 & $\begin{array}{l}\text { Increase fluid to promote adequate } \\
\text { breast flow }\end{array}$ & 3.74 & 0.44 & HL & 2.54 & 0.50 & HL \\
\hline 27 & $\begin{array}{l}\text { Sleeping on the same bed with your } \\
\text { baby }\end{array}$ & 3.90 & 0.31 & HL & 2.82 & 0.39 & HL \\
\hline Cluster Total & $\mathbf{7 1 . 3}$ & & & $\mathbf{5 1 . 3 5}$ & & \\
\hline Cluster Mean & $\mathbf{3 . 1 0}$ & $\mathbf{0 . 3 7}$ & HL & $\mathbf{2 . 2 3}$ & $\mathbf{0 . 4 1}$ & LL \\
\hline
\end{tabular}

Table 2 above shows that high mean ratings ( 2.50 and above) were obtained by nursing mothers, with secondary education and below, for items $6,7,9,11,12,14,15,16,17,18,19,20,21,23,24,25,26$ and 27, indicating high level of practice of exclusive breastfeeding. Conversely, low mean ratings were obtained by the same category of respondents (nursing mothers with secondary education and below) for items 5, 8, 10 and 22, thereby indicating low level of exclusive breast-feeding. A grand mean of 3.10, with standard deviation of 0.37 , was recorded for the nursing mothers, thereby showing that nursing mothers, with secondary education and below, practice exclusive breast-feeding at a high level.

Nursing mothers with tertiary education, on the other hand, had high mean ratings ( 2.50 and above) for items 6 , $11,14,16,17,18,19,20,21,23,26$ and 27 . Conversely, low mean ratings were obtained by the same category of respondents for items $5,7,8,9,10,12,15,22,24$ and 25 . This category of nursing mothers had a grand mean of 2.23 , with standard deviation of 0.41 , thereby indicating that they practice exclusive breastfeeding at a low level.

Research Question Three: What are the breastfeeding practices of nursing mothers in Enugu State that adopt exclusive breast feeding in relation to their ages?

Table 3.Mean ratings of nursing mothers in Enugu State regarding their exclusive breastfeeding practices, in relation to their ages

\begin{tabular}{llllllll}
\hline S/N & Items & \multicolumn{3}{c}{ Below 25yrs $=\mathbf{8 7}$} & \multicolumn{2}{c}{ 25yrs \& above $=\mathbf{3 1 8}$} \\
\cline { 3 - 8 } & & Mean & SD & Decision & Mean & SD & Decision \\
\hline 5 & $\begin{array}{l}\text { Initiation of breast-feeding within a half hour } \\
\text { of birth }\end{array}$ & 2.86 & 0.59 & HL & 1.22 & 0.41 & LL \\
\hline 6 & $\begin{array}{l}\text { Making sure the baby gets the first yellow milk } \\
\text { which is the first immunization to the baby. }\end{array}$ & 4.00 & 0.00 & HL & 3.50 & 0.59 & HL \\
\hline 7 & Feeding the baby on demand & 4.00 & 0.00 & HL & 2.59 & 0.60 & HL \\
\hline 8 & $\begin{array}{l}\text { Expression of breast milk when away from } \\
\text { home }\end{array}$ & 1.59 & 0.90 & LL & 1.00 & 0.00 & LL \\
\hline 9 & Breast feed in the public without shame & 3.38 & 0.49 & HL & 2.03 & 0.64 & LL \\
\hline 10 & $\begin{array}{l}\text { Continuing breastfeeding for six months even } \\
\text { when pregnant }\end{array}$ & 1.17 & 0.38 & LL & 1.00 & 0.00 & LL \\
\hline 11 & Breastfeed up to 8-10 times in 24 hours & 4.00 & 0.00 & HL & 3.31 & 0.63 & HL \\
\hline
\end{tabular}




\begin{tabular}{|c|c|c|c|c|c|c|c|}
\hline 12 & $\begin{array}{l}\text { After introduction of complimentary feeds at } \\
\text { six months continued breastfeeding up to one } \\
\text { year. }\end{array}$ & 4.00 & 0.00 & $\mathrm{HL}$ & 2.90 & 1.03 & $\mathrm{HL}$ \\
\hline 13 & $\begin{array}{l}\text { After introduction of complimentary feeds at } \\
\text { six months continued breastfeeding up to two } \\
\text { years }\end{array}$ & NIL & NIL & & NIL & NIL & \\
\hline 14 & Breastfeed until the baby is satisfied & 3.70 & 0.46 & $\mathrm{HL}$ & 2.74 & 0.46 & $\mathrm{HL}$ \\
\hline 15 & $\begin{array}{l}\text { No giving of artificial teat or pacifiers to } \\
\text { breastfeeding infants }\end{array}$ & 4.00 & 0.00 & HL & 2.90 & 0.77 & $\mathrm{HL}$ \\
\hline 16 & $\begin{array}{l}\text { Feeding the baby without food other than } \\
\text { breast milk for the first six months }\end{array}$ & 4.00 & 0.00 & $\mathrm{HL}$ & 3.67 & 0.49 & $\mathrm{HL}$ \\
\hline 17 & $\begin{array}{l}\text { Breastfeeding the baby without giving water } \\
\text { for the first six months }\end{array}$ & 4.00 & 0.00 & $\mathrm{HL}$ & 3.35 & 0.55 & $\mathrm{HL}$ \\
\hline 18 & $\begin{array}{l}\text { Ensures that baby's mouth is well attached to } \\
\text { the areola for the baby to get enough milk }\end{array}$ & 4.00 & 0.00 & $\mathrm{HL}$ & 3.04 & 0.66 & $\mathrm{HL}$ \\
\hline 19 & $\begin{array}{l}\text { Making sure that baby is not sucking the nipple } \\
\text { of the breast to avoid sore nipple }\end{array}$ & 4.00 & 0.00 & $\mathrm{HL}$ & 3.78 & 0.69 & $\mathrm{HL}$ \\
\hline 20 & $\begin{array}{l}\text { Proper massaging of baby's back to ensure } \\
\text { adequate belching }\end{array}$ & 4.00 & 0.00 & $\mathrm{HL}$ & 3.06 & 0.60 & $\mathrm{HL}$ \\
\hline 21 & $\begin{array}{l}\text { Ensure good personal hygiene to protect the } \\
\text { baby from having diarrhea }\end{array}$ & 4.00 & 0.00 & $\mathrm{HL}$ & 3.58 & 0.51 & $\mathrm{HL}$ \\
\hline 22 & $\begin{array}{l}\text { Continuing breast milk as it does not sour if a } \\
\text { mother does not breastfeed her baby for some } \\
\text { days }\end{array}$ & 1.22 & 0.42 & LL & 1.00 & 0.00 & LL \\
\hline 23 & Breastfeeding the baby adequately at night & 4.00 & 0.00 & HL & 3.36 & 0.60 & HL \\
\hline 24 & $\begin{array}{l}\text { Practising rooming in which allow mother and } \\
\text { infant to remain together } 24 \text { hours for the first } \\
\text { day of life }\end{array}$ & 4.00 & 0.00 & $\mathrm{HL}$ & 2.62 & 0.83 & $\mathrm{HL}$ \\
\hline 25 & $\begin{array}{l}\text { Having sex during breastfeeding as it does no } \\
\text { harm to the baby }\end{array}$ & 4.00 & 0.00 & $\mathrm{HL}$ & 2.08 & 0.57 & LL \\
\hline 26 & Increase fluid to promote adequate breast flow & 4.00 & 0.00 & $\mathrm{HL}$ & 3.04 & 0.72 & $\mathrm{HL}$ \\
\hline \multirow[t]{3}{*}{27} & Sleeping on the same bed with your baby & 4.00 & 0.00 & HL & 3.31 & 0.63 & HL \\
\hline & Cluster Total & 77.92 & & & $\mathbf{5 9 . 0 8}$ & & \\
\hline & Cluster Mean & 3.39 & 0.14 & HL & 2.57 & 0.52 & HL \\
\hline
\end{tabular}

Table 3 shows that nursing mothers below 25 years old had high mean ratings ( 2.50 and above) for items $5,6,7$, $9,11,12,14,15,16,17,18,19,20,21,23,24,25,26$ and 27 . The grand mean recorded for this category of respondents was 3.39 , with standard deviation of 0.14 , thereby showing that nursing mothers in Enugu State, whose ages are below 25 years, generally practice exclusive breastfeeding to a high level.

Table 3 also shows that high mean ratings ( 2.50 and above) were obtained by nursing mothers, aged 25 years and above, for items $6,7,11,12,14,15,16,17,18,19,20,21,23,24,26$ and 27. The grand mean was 2.57, with standard deviation of 0.52 . This invariably means that the nursing mothers aged 25 years and above generally had high level of practice of exclusive breastfeeding.

Research Question four: What are the breast-feeding practices of nursing mothers in Enugu State that adopt exclusive breast-feeding in relation to their parity? 
Table 4. Mean ratings of nursing mothers on their exclusive breast-feeding practices in relation to their parity

\begin{tabular}{|c|c|c|c|c|c|c|c|}
\hline \multirow[t]{2}{*}{$\mathbf{S} / \mathbf{N}$} & \multirow[t]{2}{*}{ Items } & \multicolumn{3}{|c|}{ Parity 1-4 times = 331} & \multicolumn{3}{|c|}{5 times $\&$ above $=74$} \\
\hline & & Mean & SD & Decision & Mean & SD & Decision \\
\hline 5 & $\begin{array}{l}\text { Initiation of breast-feeding within a half hour } \\
\text { of birth. }\end{array}$ & 1.70 & 0.85 & LL & 1.00 & 0.00 & LL \\
\hline 6 & $\begin{array}{l}\text { Making sure the baby gets the first yellow } \\
\text { milk which is the first immunization to the } \\
\text { baby. }\end{array}$ & 3.79 & 0.41 & HL & 2.81 & 0.43 & HL \\
\hline 7 & Feeding the baby on demand. & 3.12 & 0.67 & HL & 1.88 & 0.33 & LL \\
\hline 8 & $\begin{array}{l}\text { Expression of breast milk when away from } \\
\text { home }\end{array}$ & 1.15 & 0.53 & LL & 1.00 & 0.00 & $\overline{\mathrm{LL}}$ \\
\hline 9 & Breast feed in the public without shame. & 2.57 & 0.67 & $\mathrm{HL}$ & 1.19 & 0.39 & LL \\
\hline 10 & $\begin{array}{l}\text { Continuing breastfeeding for six months even } \\
\text { when pregnant. }\end{array}$ & 1.05 & 0.21 & LL & 1.00 & 0.00 & LL \\
\hline 11 & Breastfeed up to $8-10$ times in 24 hours. & 3.64 & 0.48 & $\mathrm{HL}$ & 2.62 & 0.54 & $\mathrm{HL}$ \\
\hline 12 & $\begin{array}{l}\text { After introduction of complimentary feeds at } \\
\text { six months continued breastfeeding up to one } \\
\text { year. }\end{array}$ & 3.52 & 0.64 & $\mathrm{HL}$ & 1.42 & 0.50 & $\overline{\mathrm{LL}}$ \\
\hline 13 & $\begin{array}{l}\text { After introduction of complimentary feeds at } \\
\text { six months continued breastfeeding up to two } \\
\text { years }\end{array}$ & . & . & & . & . & \\
\hline 14 & Breastfeed until the baby is satisfied & 3.17 & 0.42 & $\mathrm{HL}$ & 1.96 & 0.20 & LL \\
\hline 15 & $\begin{array}{l}\text { No giving of artificial teat or pacifiers to } \\
\text { breastfeeding infants }\end{array}$ & 3.44 & 0.52 & $\mathrm{HL}$ & 1.78 & 0.41 & LL \\
\hline 16 & $\begin{array}{l}\text { Feeding the baby without food other than } \\
\text { breast milk for the first six months }\end{array}$ & 3.92 & 0.28 & HL & 2.96 & 0.20 & HL \\
\hline 17 & $\begin{array}{l}\text { Breastfeeding the baby without giving water } \\
\text { for the first six months }\end{array}$ & 3.63 & 0.48 & HL & 2.84 & 0.37 & HL \\
\hline 18 & $\begin{array}{l}\text { Ensures that baby's mouth is well attached to } \\
\text { the areola for the baby to get enough milk }\end{array}$ & 3.47 & 0.50 & HL & 2.24 & 0.62 & LL \\
\hline 19 & $\begin{array}{l}\text { Making sure that baby is not sucking the } \\
\text { nipple of the breast to avoid sore nipple }\end{array}$ & 4.00 & 0.00 & HL & 3.04 & 1.16 & HL \\
\hline 20 & $\begin{array}{l}\text { Proper massaging of baby's back to ensure } \\
\text { adequate belching }\end{array}$ & 3.47 & 0.50 & HL & 2.35 & 0.48 & LL \\
\hline 21 & $\begin{array}{l}\text { Ensure good personal hygiene to protect the } \\
\text { baby from having diarrhea }\end{array}$ & 3.83 & 0.38 & $\mathrm{HL}$ & 2.96 & 0.20 & HL \\
\hline 22 & $\begin{array}{l}\text { Continuing breast milk as it does not sour if a } \\
\text { mother does not breastfeed her baby for some } \\
\text { days }\end{array}$ & 1.06 & 0.23 & LL & 1.00 & 0.00 & LL \\
\hline 23 & Breastfeeding the baby adequately at night & 3.65 & 0.48 & HL & 2.81 & 0.59 & HL \\
\hline 24 & $\begin{array}{l}\text { Practising rooming in which allow mother and } \\
\text { infant to remain together } 24 \text { hours for the first } \\
\text { day of life }\end{array}$ & 3.25 & 0.61 & HL & 1.39 & 0.49 & LL \\
\hline 25 & $\begin{array}{l}\text { Having sex during breastfeeding as it does no } \\
\text { harm to the baby }\end{array}$ & 2.72 & 0.86 & HL & 1.49 & 0.50 & LL \\
\hline 26 & Increase fluid to promote adequate breast flow & 3.53 & 0.51 & HL & 2.00 & 0.00 & LL \\
\hline \multirow[t]{3}{*}{27} & Sleeping on the same bed with your baby & 3.65 & 0.48 & HL & 2.59 & 0.49 & HL \\
\hline & Cluster Total & 67.33 & & & 44.33 & & \\
\hline & Cluster Mean & 2.93 & 0.47 & HL & 1.93 & 0.34 & LL \\
\hline
\end{tabular}


Table 4 above shows that nursing mothers with parity of 1-4 times had high mean ratings (2.50 and above) for items $6,7,9,11,12,14,15,16,17,18,19,20,21,23,24,25,26$ and 27, with grand mean of 2.93 and standard deviation of 0.47 .

Thus, the nursing mothers, with parity of 1-4 times generally had high level of practice of exclusive breast-feeding. For the nursing mothers with parity of 5 times and above, high mean ratings were recorded only for items $6,11,16,17,19,21,23$ and 27. Low mean ratings were recorded for the remaining items (items 5, 7, 8, $9,10,12,14,15,18,20,22,24,25$ and 26. A grand mean of 1.93, with standard deviation of 0.34 , was obtained for all the 23 items, for this category of respondents. This shows that the nursing mothers with parity of 5 times and above practice exclusive breast-feeding to a low level.

Research Question Five: What are the breast-feeding practices of nursing mothers in Enugu State that adopt exclusive breast-feeding in relation to their marital status?

Table 5. Mean Ratings of Nursing Mothers in Enugu State on their Exclusive Breast-feeding practices in relation to their marital status

\begin{tabular}{|c|c|c|c|c|c|c|c|}
\hline \multirow[t]{2}{*}{$\mathbf{S} / \mathbf{N}$} & \multirow[t]{2}{*}{ Items } & \multicolumn{3}{|c|}{ Married $=402$} & \multicolumn{3}{|c|}{ Single $=3$} \\
\hline & & Mean & SD & Decision & Mean & SD & Decision \\
\hline 5 & $\begin{array}{l}\text { Initiation of breast-feeding within a half hour of } \\
\text { birth }\end{array}$ & 1.57 & 0.82 & LL & 1.00 & 0.00 & LL \\
\hline 6 & $\begin{array}{l}\text { Making sure the baby gets the first yellow milk } \\
\text { which is the first immunization to the baby. }\end{array}$ & 3.62 & 0.53 & $\mathrm{HL}$ & 1.67 & 0.58 & LL \\
\hline 7 & Feeding the baby on demand & 2.91 & 0.77 & $\mathrm{HL}$ & 1.00 & 0.00 & LL \\
\hline 8 & $\begin{array}{l}\text { Expression of breast milk when away from } \\
\text { home }\end{array}$ & 1.13 & 0.48 & LL & 1.00 & 0.00 & LL \\
\hline 9 & Breast feed in the public without shame & 2.33 & 0.82 & LL & 1.00 & 0.00 & LL \\
\hline 10 & $\begin{array}{l}\text { Continuing breastfeeding for six months even } \\
\text { when pregnant }\end{array}$ & 1.04 & 0.19 & LL & 1.00 & 0.00 & LL \\
\hline 11 & Breastfeed up to $8-10$ times in 24 hours & 3.47 & 0.60 & HL & 1.33 & 0.58 & LL \\
\hline 12 & $\begin{array}{l}\text { After introduction of complimentary feeds at six } \\
\text { months continued breastfeeding up to one year. }\end{array}$ & 3.15 & 1.01 & HL & 1.00 & 0.00 & LL \\
\hline 13 & $\begin{array}{l}\text { After introduction of complimentary feeds at six } \\
\text { months continued breastfeeding up to two years }\end{array}$ & . & & & . & . & \\
\hline 14 & Breastfeed until the baby is satisfied & 2.96 & 0.59 & HL & 1.00 & 0.00 & LL \\
\hline 15 & $\begin{array}{l}\text { No giving of artificial teat or pacifiers to } \\
\text { breastfeeding infants }\end{array}$ & 3.15 & 0.80 & HL & 1.00 & 0.00 & LL \\
\hline 16 & $\begin{array}{l}\text { Feeding the baby without food other than breast } \\
\text { milk for the first six months }\end{array}$ & 3.75 & 0.43 & HL & 2.00 & 0.00 & LL \\
\hline 17 & $\begin{array}{l}\text { Breastfeeding the baby without giving water for } \\
\text { the first six months }\end{array}$ & 3.50 & 0.54 & HL & 2.00 & 0.00 & LL \\
\hline 18 & $\begin{array}{l}\text { Ensures that baby's mouth is well attached to } \\
\text { the areola for the baby to get enough milk }\end{array}$ & 3.26 & 0.68 & HL & 1.00 & 0.00 & LL \\
\hline 19 & $\begin{array}{l}\text { Making sure that baby is not sucking the nipple } \\
\text { of the breast to avoid sore nipple }\end{array}$ & 3.85 & 0.57 & HL & 1.00 & 0.00 & LL \\
\hline 20 & $\begin{array}{l}\text { Proper massaging of baby's back to ensure } \\
\text { adequate belching }\end{array}$ & 3.27 & 0.65 & HL & 2.00 & 0.00 & LL \\
\hline 21 & $\begin{array}{l}\text { Ensure good personal hygiene to protect the } \\
\text { baby from having diarrhea }\end{array}$ & 3.68 & 0.47 & HL & 2.00 & 0.00 & LL \\
\hline 22 & Continuing breast milk as it does not sour if a & 1.05 & 0.21 & LL & 1.00 & 0.00 & LL \\
\hline
\end{tabular}


mother does not breastfeed her baby for some

days

\begin{tabular}{llllllll}
\hline 23 & Breastfeeding the baby adequately at night & 3.51 & 0.56 & HL & 1.00 & 0.00 & LL \\
\hline 24 & $\begin{array}{l}\text { Practising rooming in which allow mother and } \\
\text { infant to remain together 24 hours for the first } \\
\text { day of life }\end{array}$ & 2.93 & 0.92 & HL & 1.00 & 0.00 & LL \\
\hline 25 & $\begin{array}{l}\text { Having sex during breastfeeding as it does no } \\
\text { harm to the baby }\end{array}$ & 2.50 & 0.93 & HL & 1.00 & 0.00 & LL \\
\hline 26 & Increase fluid to promote adequate breast flow & 3.26 & 0.75 & HL & 2.00 & 0.00 & LL \\
\hline 27 & Sleeping on the same bed with your baby & 3.47 & 0.62 & HL & 2.00 & 0.00 & LL \\
\hline & Cluster Total & $\mathbf{6 3 . 3 6}$ & & & $\mathbf{2 9}$ & & \\
\hline & Cluster Mean & $\mathbf{2 . 7 5}$ & $\mathbf{0 . 6 1}$ & $\mathbf{H L}$ & $\mathbf{1 . 2 6}$ & $\mathbf{0 . 0 5}$ & LL \\
\hline
\end{tabular}

Table 5 shows that the married nursing mothers had high mean ratings ( 2.50 and above) for items $6,7,11,12,14$, $15,16,17,18,19,20,21,23,24,25,26$ and 27 . Accordingly, low mean ratings were obtained by the married nursing mothers for items 5, 8, 9, 10 and 22 only. A grand mean of 2.75, with standard deviation of 0.61 , was obtained for all the 23 items, thereby indicating that the married nursing mothers in Enugu State generally practice exclusive breast-feeding to a high level.

For the unmarried or single nursing mothers, low mean ratings were recorded for all the 23 items (items 5-27). A grand mean of 1.26 was obtained for all the items. This shows that the single or unmarried nursing mothers in Enugu State generally have low level of practice of exclusive breast-feeding.

\section{Discussion}

\subsection{Breast Feeding Practices of Nursing Mothers in Enugu State That Adopt EBF}

The result in table I revealed a grand mean of 2.75 with standard deviation of 0.6 for all the components of exclusive breastfeeding practices. This result indicates that majority of the nursing mothers in Enugu state practice EBF to a high level. This result contradicts the findings of Oliko (2009) which stated that despite the laudable benefits and objectives of EBF, mothers in developing countries such as Nigeria and its rural settings seem not to wholesomely adopt and practice EBF. Unfortunately a critical examination of the components of indices of EBF as presented in table I showed that mothers in the study area practice initiation of EBF within a half-hour and continuing of breast-feeding for six months even when they are pregnant to a low level. This could imply that mothers do not consider the two aspects as important. The result is unexpected and contradicted UNICEF and WHO recommendation that babies should be put to breast not later than one -hour after birth as it stimulates the release of prolactin and oxytocin - the breast secreting and flowing hormones respectively. Also, late initiation prevents the baby from getting the first and best quality yellowish breast milk (colostrum) which is the baby's first immunization against infective diseases (UNICEF \& WHO, 2003).

\subsection{Differences of Socio-Demographic Variable on Breast Feeding Practice of Nursing Mothers in Enugu State} That Adopt EBF

Evidence has shown that some socio-demographic factors may significantly affect mothers' practice of exclusive breast feeding (Matusiak, 2005; Amadhila, 2005; UNICEF, 2000). These variables have been conceived in this study as level of education, age, parity, and marital status.

Regarding the influence of level of education on breast-feeding practice of nursing mothers that adopt exclusive breast-feeding, result in table 2 indicates a grand mean of 3.10 with standard deviation of 0.37 for nursing mothers with secondary education and below and a grand mean of 2.23 with standard deviation of 0.41 for nursing mothers with tertiary education. Maternal education is strongly associated with EBF practices (Alemayehu, Haidar \& Habte, 2009) and is an important maternal predictor of EBF practice (Onah, Osuorah, Ebenebe et al., 2014).UNICEF (2000) states that maternal level of education plays a significant role on adoption and practice of EBF as educated mothers tend to adopt and practice EBF more conveniently than their uneducated counterparts. Evidence show that the practice of exclusive breastfeeding among respondents on no level of education is the highest at $46.2 \%$, while post-secondary level is the lowest at $26.1 \%$ (Odindo, Loum, Alwar et al., 2014). Mother's education level is a predictor of exclusive breastfeeding practice (Sefene, Birhanu, 
Awoke et al., 2013) and a study documents that mothers who reported practicing EBF for 6 months, were more educated (Qureshi, Oche, Sadiq et al., 2011). On the contrast, the interruption of exclusive breastfeeding for infants up to 6 months is associated with lower maternal educational level (do Nascimento, Reis, Franco et al., 2010).

In Nigeria, a study records that non-EBF is attributable to primary and no maternal education (Ogbo, Page, Idoko et al., 2018). The education of the mother had a direct influence on exclusive breastfeeding (Radhakrishnan \& Balamuruga, 2012). The knowledge and practice of exclusive breastfeeding was found to increase with better educational status of the women (Ogbonna \& Daboer, 2007). A high maternal educational level is an important factor for EBF practice (Uchendu, Ikefuna \& Emodi, 2009). Level of education of the mother is significant with exclusive breastfeeding at $\mathrm{P} \leq 0.05$ (Limo, 2018). Higher education of mothers positively associated with exclusive breastfeeding (Centers for Disease Control and Prevention, CDC, 2007). EBF is associated with having secondary school education (Aidam, Perez-Escamilla, Lartey et al., 2005). Mothers who held post-graduate university degrees were 3.76 times more likely to breastfeed exclusively for 6 months than those without a university degree (Jessri, Farmer, Maximova et al., 2013). Mothers with a low education level tend to discontinue EBF (Barría, Santander \& Victoriano, 2008).

The finding of this study may be surprising, because one would expect nursing mothers with higher educational qualification to practice EBF more than their counterparts because, since knowledge is power, they stand the better chance of being aware of importance of new trends in health promotion strategies which EBF is one. More so, mothers in Enugu who are of tertiary group do not practice EBF to a high level because they constitute the major population of publicly employed (public servants) and may not have the time to practice EBF to a high level. Also, because of their social class, they are fashion conscious and may not afford to breast-feed in the public and on demand even if they have the time.

Regarding the difference of age on breast-feeding practices of nursing mothers, result in table 3 indicates a grand mean of 3.39, with standard deviation of 0.14 for nursing mothers aged below 25 years and a grand mean of 2.57 , with standard deviation of 0.52 for nursing mothers aged 25 years and above. The result of this study is not against the background of the available literature. The result of Sika-Bright (2010) observed that age of mother affected the way infants are fed, and that young mothers below 22 years of age were less likely to exclusively breast feed, like wise mothers who were never married. A study reports that the odds of mothers aged 25 to 35 years to practice EBF was up to 8.9 times more than mothers aged less than 25 years (Asfaw, Argaw \& Kefene, 2015). Maternal age was significantly associated with exclusive breastfeeding (Jones, Kogan, Singh et al., 2011) and maternal age 15-24 years is a predictor of exclusive breast-feeding practice (Sorato, 2016; Newton, Chaudhuri, Grossman et al., 2009). Mothers who reported practicing EBF for 6 months were older (Qureshi, Oche, Sadiq et al., 2011), the knowledge and practice of exclusive breastfeeding was found to increase with increasing maternal age (Ogbonna \& Daboer, 2007). Older age of mothers positively associated with exclusive breastfeeding (Centers for Disease Control and Prevention, CDC, 2007). Similarly, risk factors for early weaning include maternal age below 20 years (Chudasama, Patel \& Kavishwar, 2009).

Regarding the difference of parity on breastfeeding practices of nursing mothers that adopt EBF, result in table 4 indicates a grand mean of 2.93, with standard deviation of 0.47 for nursing mothers with parity of 1-4 times and a grand mean of 1.93 , with standard deviation of 0.34 for nursing mothers with parity of 5 times and above. The result agreed with Igbokwe (2004) who states that multiparous mothers may not adopt EBF because they use the traditional method of breast- feeding (mixed feeding) in feeding their babies. He also said that mothers with one or two children tend to embrace the innovation of EBF over traditional method of breastfeeding. Number of children had a direct influence on exclusive breastfeeding (Radhakrishnan \& Balamuruga, 2012) and the number of children of the mother is significant with exclusive breastfeeding at $\mathrm{P} \leq 0.05$ (Limo, 2018). Family size of 3 is a predictor of exclusive breast-feeding practice (Sorato, 2016). In Nigeria, a study records that non-EBF is attributable to lower number of children, 1-3 (Ogbo, Page, Idoko et al., 2018). Parity is a predictor of exclusive breastfeeding practice (Sefene, Birhanu, Awoke et al., 2013). Mothers who were multiparous were more likely to achieve their exclusive breastfeeding intention (Perrine, Scanlon, Li et al., 2012; Tan, 2011). Mothers who reported practicing EBF for 6 months were multi-parous (Qureshi, Oche, Sadiq et al., 2011). Mothers of previous children were more likely to breastfeed exclusively for 6 months (Jessri, Farmer, Maximova et al., 2013) and mothers who had one or more previous pregnancies were more likely to practice EBF (Egwuda \& Bako, 2018). Contrarily, risk factors for early weaning include primiparity (Chudasama, Patel \& Kavishwar, 2009).

Regarding the marital status of breast feeding practices of nursing mothers that adopt EBF, result in table 5 indicates a grand mean of 2.75 with standard deviation of 0.61 for married nursing mothers and a grand mean of 1.26, with standard deviation 0.05 for single nursing mothers. The result was in consonance with the findings of 
Sika-Bright, (2010) and Kok (2011) which show that EBF was high in married nursing mothers. Mothers who were married were more likely to achieve their exclusive breastfeeding intention (Perrine, Scanlon, Li et al., 2012). Marital status is strongly associated with EBF practices (Alemayehu, Haidar \& Habte, 2009; Tampah-Naah \& Kumi-Kyereme, 2013). A study reports that marital status is among the factors that significantly influence exclusive breastfeeding in Ghana (Adzraku, 2015). Rates of exclusive breastfeeding were significantly lower among infants born to unmarried mothers compared with married mothers (Centers for Disease Control and Prevention, CDC, 2007). Withdrawal of exclusive breastfeeding was positively associated with single marital status (Barría, Santander \& Victoriano, 2008) and single mothers have less odds to practice EBF up to six months (Mgongo, Mosha, Uriyo et al., 2013).

\section{Implications of the Study}

1. The health of a mother and child is a key and agent of a productive economy, therefore if for any reason their health is jeopardized, the aim of having a healthy and wealthy nation is missed. There is a great danger for the future, since majority of the nursing mothers according to the findings of the study initiated EBF later than one hour after birth. It implies that they do not recognize the importance of giving their babies enough of the first best quality yellowish breast milk (colostrums) which is the baby's first immunization as it contains anti-infective agents such as immunoglobulin (Ig) A that protects the intestinal mucosa against entry of pathogenic bacteria entero-viruses there by predisposing those babies to many childhood diseases.

2. Furthermore, the study reveals that publicly employed nursing mothers (public servants) find it difficult to practice EBF for 6 months and as a result discontinues EBF immediately their maternity leave stops. This was due to the fact that their maternity leave usually ends between 3-4 months and that calls for the need to extend maternity leave of nursing mothers to 6 months because that is when complementary feeds are usually introduced and breast feeding continues.

3. More serious EBF education is needed to reduce the influx of sick babies in the hospitals there by reducing the workload of the health workers and given them time to concentrate more on the sick adults.

\section{Conclusion}

Exclusive breast-feeding for the first six months of life is a natural and cost-effective means of providing a highly nutritious milk for newborns and minimizing the risk of infection. While EBF is high in the study area, the practice is greatly influenced by socio demographic variables. Hence, a more elaborate campaign in rural areas on EBF is advocated to enhance the knowledge of nursing mothers on the benefits of EBF and thereby minimize the effect of socio-demographic variables on the practices of EBF.

\section{Recommendations}

1. Mothers should endeavor to exclusively breast feed their young ones at least for six months to enable them get the gains of good health development before introduction of complementary feeds and continues breast feeding for at least one year as this will help to reduce the time and money they spent in taking their children to hospital.

2. More intensive EBF campaigns as has been mounted on the air PATHS II should be carried in form of practical to the general public during August meetings and mass return as the case may be for better assimilation and understanding of critical issues that may be hindering EBF practices.

3. Strict inspection of implementation of the breast-feeding policies in the health facilities and extension of maternity leave to six months.

\section{References}

Adzraku, K. K. (2015). Factors that Influence Exclusive Breastfeeding in Ghana. Doctoral dissertation, University Of Ghana.

Aidam, B. A., Perez-Escamilla, R., \& Lartey, A. (2005). Factors associated with exclusive breastfeeding in Accra, Ghana. European Journal of Clinical Nutrition, 59(6), 789. https://doi.org/10.1038/sj.ejcn.1602144

Alemayehu, T., Haidar, J., \& Habte, D. (2009). Determinants of exclusive breastfeeding practices in Ethiopia. Ethiopian Journal of Health Development, 23(1). https://doi.org/10.4314/ejhd.v23i1.44832

Amadhila, J. N. (2005). Factors that influence exclusive breastfeeding in Windhoek District in Namibia. Doctoral dissertation, University of the Western Cape.

American Academy of Pediatrics (AAP). (2000). Breastfeeding and the use of human Milk. Pediatrics, 100(6), 1035-1039. https://doi.org/10.1542/peds.100.6.1035 
Asfaw, M. M., Argaw, M. D., \& Kefene, Z. K. (2015). Factors associated with exclusive breastfeeding practices in Debre Berhan District, Central Ethiopia: a cross sectional community based study. International Breastfeeding Journal, 10(1), 23. https://doi.org/10.1186/s13006-015-0049-2

Barría, R. M., Santander, G., \& Victoriano, T. (2008). Factors associated with exclusive breastfeeding at 3 months postpartum in Valdivia, Chile. Journal of Human Lactation, 24(4), 439-445. https://doi.org/10.1177/0890334408322263

Cai, X., Wardlaw, T., \& Brown, D. W. (2012). Global trends in exclusive breastfeeding. International Breastfeeding Journal, 7(1), 12. https://doi.org/10.1186/1746-4358-7-12

Centers for Disease Control and Prevention. (2007). Breastfeeding trends and updated national health objectives for exclusive breastfeeding--United States, birth years 2000-2004. MMWR. Morbidity and Mortality Weekly Report, 56(30), 760.

Chudasama, R. K., Patel, P. C., \& Kavishwar, A. B. (2009). Determinants of exclusive breastfeeding in south Gujarat region of India. Journal of Clinical Medicine Research, 1(2), 102. https://doi.org/10.4021/jocmr2009.06.1242

Chung, M. R., \& Magula, W. G. (2007). Breastfeeding and maternal and infant health outcomes in developed countries Rock Ville. MD: US Department of Health and Human Service.

Do Nascimento, M. B. R., Reis, M. A. M., Franco, S. C., Issler, H., Ferraro, A. A., \& Grisi, S. J. F. (2010). Exclusive breastfeeding in southern Brazil: prevalence and associated factors. Breastfeeding Medicine, 5(2), 79-85. https://doi.org/10.1089/bfm.2009.0008

Egwuda, L., \& Bako, I. A. (2018). Prevalence of exclusive breastfeeding among mothers of infants aged 0-6 months in Makurdi, Nigeria: a cross-sectional survey. J. BioMed. Research \& Clinical Practice, 1(2), $148-156$.

Fewtrell, M. S., Morgan, J. B., \& Duggan, C. (2007). Optimal duration of exclusive breastfeeding: what is the evidence to support current recommendations?. The American Journal of Clinical Nutrition, 85(2), 635S-638S. https://doi.org/10.1093/ajcn/85.2.635S

Igbokwe, C. C. (2004). Levels and determinants of non-acceptance of family planning practices among couples in Nsukka. L.G.A of Enugu State: Unpublished Projects Report. UNN.

Jessri, M., Farmer, A. P., \& Maximova, K. (2013). Predictors of exclusive breastfeeding: observations from the Alberta pregnancy outcomes and nutrition (APrON) study. BMC Pediatrics, 13(1), 77. https://doi.org/10.1186/1471-2431-13-77

Jones, J. R., Kogan, M. D., \& Singh, G. K. (2011). Factors associated with exclusive breastfeeding in the United States. Pediatrics, peds-2011. https://doi.org/10.1542/peds.2011-0841d

Kok, L. T. (2011). Factors associated with exclusive breast-feeding among infants less than six months of age in Peninsular Malaysia. International Breast- feeding Journal, 72, 820-826.

Ladomenou, F., Moschandreas, J., \& Kafatos, A. (2010). Protective effect of exclusive breastfeeding against infections during infancy: a prospective study. Archives of Disease in Childhood, 95(12), 1004-1008. https://doi.org/10.1136/adc.2009.169912

Limo, F. J. (2018). Factors Associated with Exclusive Breastfeeding among Mothers of Children Aged Six Months and Below Attending Baringo County Refferal Hospital, Kabarnet. Doctoral dissertation, JKUAT-COHES.

Matusiak, M. M (2005). A cultural prospective of the feeding habits. The Internet Journal of Nutrition and Wellness, 4(1), 524.

Mgongo, M., Mosha, M. V., \& Uriyo, J. G. (2013). Prevalence and predictors of exclusive breastfeeding among women in Kilimanjaro region, Northern Tanzania: a population based cross-sectional study. International Breastfeeding Journal, 8(1), 12. https://doi.org/10.1186/1746-4358-8-12

National Population Commission. (2006). Nigeria demographic and health survey. Abuja.

Newton, K. N., Chaudhuri, J., \& Grossman, X. (2009). Factors associated with exclusive breastfeeding among Latina women giving birth at an inner-city baby-friendly hospital. Journal of Human Lactation, 25(1), 28-33. https://doi.org/10.1177/0890334408329437

Odindo, S. J., Loum, C., \& Alwar, J. (2014). Assessment of Association between Soci-economic Status and 
Breast Feeding Practices among Lactating Mothers in Siaya County. Universal Journal of Medical Science, 2(4), 51-54.

Ogbo, F. A., Page, A., \& Idoko, J. (2018). Breastfeeding in Nigeria. BMC public health, $18(1), 247$. https://doi.org/10.1186/s12889-018-5145-y

Ogbonna, C., \& Daboer, J. C. (2007). Current knowledge and practice of exclusive breastfeeding among mothers in Jos, Nigeria. Nigerian Journal of Medicine: Journal of the National Association of Resident Doctors of Nigeria, 16(3), 256-260.

Oliko, P. M. (2009). Overview of family planning and exclusive breast-feeding. The Conference of Nigerian national association of nurses and midwives (NNANM) Lagos.

Onah, S., Osuorah, D. I. C., \& Ebenebe, J. (2014). Infant feeding practices and maternal socio-demographic factors that influence practice of exclusive breastfeeding among mothers in Nnewi South-East Nigeria: a cross-sectional and analytical study. International Breastfeeding Journal, $9(1), \quad 6$. https://doi.org/10.1186/1746-4358-9-6

Perrine, C. G., Scanlon, K. S., \& Li, R. (2012). Baby-friendly hospital practices and meeting exclusive breastfeeding intention. Pediatrics, peds-2011. https://doi.org/10.1542/peds.2011-3633

Qureshi, A. M., Oche, O. M., Sadiq, U. A., \& Kabiru, S. (2011). Using community volunteers to promote exclusive breastfeeding in Sokoto State, Nigeria. Pan African Medical Journal, 10. https://doi.org/10.4314/pamj.v10i0.72215

Radhakrishnan, S., \& Balamuruga, S. S. (2012). Prevalence of exclusive breastfeeding practices among rural women in Tamil Nadu. International Journal of Health \& Allied Sciences, 1(2), 64. https://doi.org/10.4103/2278-344X.101667

Sefene, A., Birhanu, D., \& Awoke, W. (2013). Determinants of exclusive breastfeeding practice among mothers of children age less than 6 month in Bahir Dar city administration, Northwest Ethiopia; a community based cross-sectional survey. Sci J Clin Med, 2(6), 153-9. https://doi.org/10.11648/j.sjcm.20130206.12

Setegn, T., Belachew, T., \& Gerbaba, M. (2012). Factors associated with exclusive breastfeeding practices among mothers in Goba district, south east Ethiopia: a cross-sectional study. International Breastfeeding Journal, 7(1), 17. https://doi.org/10.1186/1746-4358-7-17

Sika-Bright, S. (2010). Socio-cultural factors influencing infant feeding practices of mothers attending welfare clinic in Cape Coast in Ghana.

Sorato, M. M. (2016). Levels and Predictors of Exclusive Breast Feeding Among Rural Mothers with Children age 0-12 Months in Rural Kebeles of Chencha District. Snnpr, Gamo Gofa Zone, Ethio-pia, 1, 3-77. https://doi.org/10.25141/2572-4355-2017-3.0077

Tan, K. L. (2011). Factors associated with exclusive breastfeeding among infants under six months of age in peninsular Malaysia. International Breastfeeding Journal, 6(1), 2. https://doi.org/10.1186/1746-4358-6-2

Uchendu, U. O., Ikefuna, A. N., \& Emodi, I. J. (2009). Factors associated with exclusive breastfeeding among mothers seen at the University of Nigeria Teaching Hospital. South African Journal of Child Health, 3(1).

UNICEF. (2000). The World health report of children. Geneva: The Author.

WHO, \& UNICEF. (2009). Global action plan for prevention and control of pneumonia (GAPP). Volume $\mathrm{WHO} / \mathrm{FCH} / \mathrm{CAH} / \mathrm{NCH} / \mathrm{Og}, 04$.

WHO. (2003). The global strategy for infant and young child feeding. Geneva: Switzerland. WHO \& UNICEF.

WHO. (2004). Better child and exclusive breast-feeding. Geneva: The Author.

\section{Copyrights}

Copyright for this article is retained by the author(s), with first publication rights granted to the journal.

This is an open-access article distributed under the terms and conditions of the Creative Commons Attribution license (http://creativecommons.org/licenses/by/4.0/). 